\title{
Assessing the level of economic consciousness and the level of health consciousness of the COVID-19 pandemic: Evidence from Indonesia
}

\author{
Alini Alini ${ }^{1}$ (D), Dewi Anggriani Harahap $^{2}$ (D) Andi $\operatorname{Irfan}^{3 *}$ (D), Dessyka Febria ${ }^{1}$ (D) \\ ${ }^{1}$ Department of Nursing, Faculty of Health Science, Universitas Pahlawan Tuanku Tambusai, Bangkinang, Indonesia; ${ }^{2}$ Department \\ of Midwifery, Faculty of Health Science, Universitas Pahlawan Tuanku Tambusai, Bangkinang, Indonesia; ${ }^{3}$ Department of \\ Accounting, Faculty of Economics and Social Science, Universitas Islam Negeri Sultan Syarif Kasim, Pekanbaru, Indonesia
}

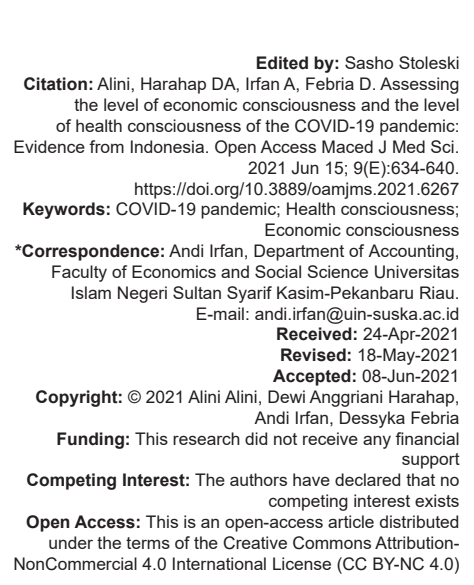

Introduction

Early 2020, the world was shocked by the mysterious pneumonia case. This case is a new type and has been reported in Wuhan, Hubei Province. The source of the transmission of this case is still uncertain, but the first case was linked to a fish market in Wuhan. From December 18, 2019, to December 29, 2019, five patients were treated with acute respiratory distress syndrome (ARDS). On March 2, 2020, the President of the Republic of Indonesia announced that Indonesia had been exposed starting from the first patient who came from Depok, West Java Province. The virus is said to be transmissible from person to person and has spread widely to more than 190 countries. On March 12, 2020, the WHO declared COVID-19 as pandemic.

It did not take a long time, all provinces in Indonesia were exposed and on average were determined as red zones. The provinces of DKI Jakarta and East Java were designated as the COVID-19 pandemic provinces because the two provinces had the most sufferers throughout Indonesia. To reduce the acceleration of the spread of COVID-19, BNPB established a national emergency status by implementing health protocols, namely, social distancing and personal distancing starting February 29, 2020, to May 29, 2020. The central government allows local governments to apply for large-scale social restrictions (PSBB). The preventive efforts undertaken by the central and regional governments have been maximal, even though the transmission by the end of 2020 has exceeded 500,000 positive patients with the growth tends to increase.

By increasing the number of people is exposed to COVID-19, it is expected that the societies will have the consciousness to maintain their health. A person's consciousness begins with his/her indifference. Furthermore, when the risk is higher, then a person feels that there is an intention, this intention tends to increase. In other words, the person needs to raise consciousness to care enough about the status quo and to consider new behaviors in managing risk [1]. The consciousness needed during the COVID-19 pandemic 
is health consciousness and economic consciousness. Health consciousness is a preventive effort against the occurrence of a disease after knowing information about one's own health [2], [3], [4] argue that people who have health consciousness, they think more about living a better and healthier life, exercising or doing enough physical activity, and also maintaining their health and taking preventive action against exposure to infectious diseases which ultimately build psychological wellness.

In addition, to slow down the acceleration of the transmission of COVID-19, economic consciousness is also needed. Voronov et al. [5] states that economic consciousness is formed due to it is influenced by individual perceptions toward economic needs. Moreover, responding to the current pandemic era, societies are expected to be more careful in maintaining health and they do not neglect economic needs. A person's economic consciousness changes as a result of practical economic thinking and individual motives, interests, and the economic foundations of the family [5]. The researcher conducted preliminary observations toward small and middle traders in Pekanbaru City who have close contact with consumers and have the highest risk of being exposed to COVID19. In general, traders do not care and are conscious of these risks. Likewise, rural communities in the green zone also do not care and are conscious of the risks of being exposed. The most important thing for them is the fulfillment of their economic needs because people do not want to depend on the government and do not want to do anything. Based on the description above, this research is important to do to assess public health consciousness and economic consciousness about the risk of being exposed to COVID-19.

\section{Literature Review and Hypothesis Development}

\section{Health consciousness level}

Hoque et al. [6] said that every individual has health consciousness, the individual looks for nutritious food and vitamins so that his/her health is maintained. $\mathrm{Hu}$ [7] states that health consciousness refers to individual orientation to prevent possible disease and improve well-being. Researchers have defined health consciousness as the tendency to focus on the individual's health [8]. Becker et al. [9] and Michaelidou and Hasan [10] argued that health consciousness is an individual's readiness to face health actions. Gould [11] classifies health consciousness into four (i.e. health self-consciousness, health alertness, health involvement, and health monitoring). Hong [3] develops the dimensions of health consciousness into five, namely, [1] integration of health behavior, [2] attention to one's health or psychological/inner state, [3] health information seeking and usage, [4] personal health responsibility, and [5] health motivation.

The integration of health behavior can be identified in four health subdimensions, namely, (1) concern for dangerous environments, (2) physical fitness, (3) personal responsibility, and (4) management of nutrition and stress [12]. From this subdimension, it is obtained the characteristics of a person who is health conscious, namely, as a person who is sensitive to health hazards, is responsible for health, and is concerned about physical health and cares about nutrition and manages stress. Jayanti and Burns [13] also found that every health problem can be integrated into everyday life. Furthermore, Dutta-Bergman [14] states that health consciousness as a healthy activity uses four healthrelated measures to measure the level of individual health consciousness on a 6-point Likert scale: Healthy eating, exercise, alcohol consumption (negative correlation), and gambling (negative correlation).

Psychological/inner state is health consciousness as a psychological or mental status, including self-consciousness of health, health consciousness, involvement, and self-monitoring of health [2]. Dutta-Bergman [15], [16], [17] also have found health indicators, namely, orientation of health information, trust in health, and health activities. Health information seeking and usage is an important factor in health consciousness and it is supported by food consumption behavior [18]. Health consciousness has been identified by Furnham and Forey [18] as consciousness about lifestyle, concern for the environment, and perceptions about medicine. Dutta-Bergman [19] states that the individual with high health consciousness seeks more health information than the individual with low health consciousness in mass media, online newspapers, and social media [17]. When it is compared to person who has low consciousness, Dutta-Bergman [14] found that television and radio are preferred in seeking health information.

For personal responsibility, Dutta-Bergman [15], Basu and Dutta-Bergman [20], Dutta-Bergman and Feng [21] found that people with high health consciousness are responsible for maintaining their health and participate actively in the health community and do not behave. Health motivation is the enthusiasm of individual who aims to prevent illness and health behavior, it is seen from the behavior in obtaining health information and health-care behavior [22]. Therefore, the individual who has health consciousness, the individual is always active and consistent in behaving in a healthy manner every day, seeking information about health and its prevention and always being motivated to be healthy.

\section{Economic consciousness level}

Economic consciousness can be defined as a set of knowledge, ideas, moods, and other 
components of consciousness that reflect the individual's economic attitude and build the characteristics of their understanding and perception of the importance of the economy. Voronov [5] states that economic consciousness is characterized by acceptance or rejection of the current rules of economic activity, property ownership relationships, and social consequences. Economic consciousness is consciousness of economic concepts or mechanisms that bring transformation in society and the status of community life [23]. Economic consciousness is usually seen as a complex psychological formation that acts to control a person's economic behavior and it consists of the following interrelated components: Cognitive, motivational value, and behavior [24].

Consciousness of the need for economics is a vital and fundamental issue because the other human needs such as the need for food and clothing, education, health, and others will not be achieved and fulfilled. One of the philosophers, Karl Max, said that the economy is the basis and basis of human structure for his life, while other things, such as religion, culture, social, and political, are built on it. This shows that how the economy is a determining factor for human life. On the other hand, the general public is usually triggered by external factors to carry out economic activities, such as family pressure, social, cultural, educational or other systems, and situations so that economic activities are promoted and carried out to survive, compete, and even against the complexity of the system that has been existed.

Economic consciousness relates to (1) consciousness of human existence as an economic being consisting of material and non-material aspects, (2) consciousness of economic activities and activities is a form of economic consciousness to meet the needs of human life in material and non-material terms [25]. Abraham Maslow said that economics is a field of study that tries to solve the problem of the basic needs of human life through the galvanizing of all existing economic resources based on certain principles and theories in an economic system that is considered effective and efficient. Economic activity as something that aims to solve the problems of the principles of the necessities of human life by looking at and referring the system in principle that tries to fill these two human dimensions. For example, economic actors in producing their goods, in addition to thinking about the methods and systems of production, must also consider aspects of consumer satisfaction [26].

In the beginning, humans lived by fulfilling simple needs, such as eating, drinking, other housing, clothing, and so on. However, humans know their limitations and realize that by themselves, these needs cannot be met. There are many forms of self-fulfillment, among others, by cooperating with other people around them, so that in the end, a traditional economic system has emerged which is a very simple pattern of economic relations, based on habits and for the fulfillment of daily life only, such as eating, drinking, and clothes. In this traditional economic system, economic actors still use a sense of kinship because initially this system was built based on light needs based on hereditary habits, simple means of production and relying only on people around the environment.

At the next stage of development, the consciousness of these needs definitely raises another consciousness of meeting those needs, needs are not met if no one can provide those needs, then eventually the division of producers and consumers, producers as providers of needs, and consumers as users of needs will emerge. On the other hand, the process of fulfilling human needs both individually and communally through the supported economic systems and its implications also take into account other aspects such as equity, welfare, and human values.

\section{The Development of Hypothesis}

Everyone has consciousness of something that happens in his/her life, one of which is health consciousness. The individual who has health consciousness, it is shown to be always active and consistent in behaving in a healthy manner every day, seeking information about health and its prevention, and always being motivated to be healthy. With the COVID-19 pandemic, many societies have begun to realize the importance of health in accordance with their respective levels of consciousness. Therefore, the hypothesis can be described as follows:

There is a relationship between COVID-19 pandemic and the health consciousness level.

Apart from health consciousness, humans also need of consciousness that is vital to their lives, namely, economic of consciousness. There are so many economic needs of humans to carry out their lives, it encourages them to do everything to meet their needs. However, with the COVID-19 pandemic, quite a lot of economic sectors have been shaken up to bankruptcy. Therefore, the hypothesis can be described as follows:

There is a relationship between COVID-19 pandemic and the economic consciousness level.

The COVID-19 pandemic has shaken the level of human consciousness, both economic and health consciousness. This pandemic has caused almost all countries to impose strict health protocols and to close down business premises. This raises new problems, apart from health problems, but also economic problems. Until now, quite a lot of the economies of a country have been shaken by the COVID-19 pandemic, one of which is Indonesia. With these conditions, humans are faced with two choices, whether economic consciousness 
or health is preferred. Thus, the hypothesis can be described as follows:

The economic consciousness level is higher than the health consciousness level during COVID-19 pandemic.

\section{Research Method}

This research used quantitative through surveys and it was complemented by direct interviews with respondents. The survey was conducted on Indonesian people who were in the red, orange, yellow, and green zones through Google Forms and directly met respondents. The population used was all Indonesian citizens. The online questionnaire was designed using Google Forms and was sent to participants through various social media platforms (WhatsApp, Messenger, Facebook, and email). Researcher took a sample of all Indonesian people and specifically conducted direct interviews with people who lived in Riau Province because from the beginning of the COVID-19 pandemic, it changed a green to red zone. province:

The following is a breakdown of zones by

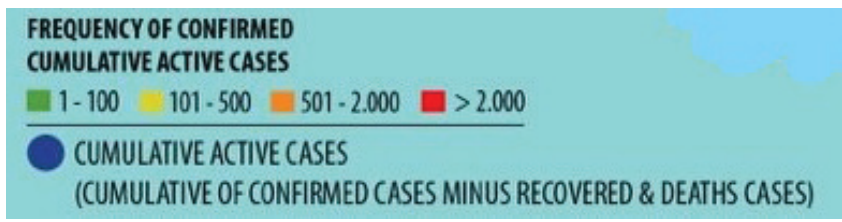

\section{Sources: National Board for Disaster Management (BNPB RI)}

The sampling method used the incidental method which directly met the society as the sample. This study used correlation data analysis to see the relationship between variable $X$ and variable $Y$. The instrument used in this study was a modification of the instruments [3], [5], [10], [11], [12], and [27].

\section{Results}

\section{Description of respondents}

Data collection in this study was using Google Forms and direct surveys to respondents, especially respondents with the unproductive age, never attend a D3 education, MSME entrepreneurs, and non-formal workers. Total responses that came from Google Forms were 183 respondents. Based on the total of the respondent, only 172 could be used because they did not pass the questionnaire validity test. The total responses collected through direct surveys were 26 respondents and all of them passed the questionnaire validity test. The following is the distribution of respondents:

Table 1 explains that the majority of respondents are in productive age (79.8\%). Aspect of education, the majority of respondents have high education (D1/D2/D3 - 18.7\%, D4/S1 - 17.2\%, and postgraduate - $28.3 \%$ ), respondents are also the majority of permanent workers (55.1\%). The insurance aspect shows that the majority of respondents do not have insurance $(52.5 \%)$. The income aspect shows that the majority of respondents do not have a definite income (40.4\%). The savings aspect shows that the majority have savings of more than IDR $5,000,000(35.4 \%)$. The aspect of health complaints shows that the majority of respondents do not have health complaints $(59.6 \%)$. The economic conditions during the COVID-19 pandemic show that the majority of respondents experience very deteriorating economic conditions. The health condition of the COVID-19 pandemic shows that the majority of respondents do not feel any complaints during this pandemic (75.3\%). The location of the majority of respondents' residence is in the red zone $(30.3 \%)$. In testing the validity and reliability of the instrument, it shows that all validation instruments with a Cronbach alpha value of 0.852 , it

Table 1: Description of respondent

\begin{tabular}{|c|c|c|}
\hline \multirow[t]{2}{*}{ Information } & \multicolumn{2}{|l|}{ Respondent } \\
\hline & Frequency & Percentage \\
\hline \multicolumn{3}{|l|}{ Age } \\
\hline Productive age & 158 & 79.8 \\
\hline Non-productive age & 40 & 20.2 \\
\hline \multicolumn{3}{|l|}{ Education } \\
\hline No school & 27 & 13.6 \\
\hline Elementary/Junior high/senior high school & 44 & 22.2 \\
\hline Diploma 1,2 , and 3 & 37 & 18.7 \\
\hline Diploma 4/undergraduated & 34 & 17.2 \\
\hline Postgraduated & 56 & 28.3 \\
\hline \multicolumn{3}{|l|}{ Profession } \\
\hline Not a permanent employee & 89 & 44.9 \\
\hline Permanent employee & 109 & 55.1 \\
\hline \multicolumn{3}{|l|}{ Health insurance } \\
\hline Does not have health insurance & 104 & 52.5 \\
\hline Have health insurance & 94 & 47.5 \\
\hline \multicolumn{3}{|l|}{ Income } \\
\hline Do not have a definite income & 80 & 40.4 \\
\hline 0 until $1,000,000$ IDR & 15 & 7.6 \\
\hline 1,000,001 until 2,500,000 IDR & 21 & 10.6 \\
\hline 2,500,001 until $5,000,000$ IDR & 52 & 26.3 \\
\hline Above $5,000,001$ IDR & 30 & 15.2 \\
\hline \multicolumn{3}{|l|}{ Saving } \\
\hline Have no a saving & 48 & 24.2 \\
\hline 0 until $1,000,000$ IDR & 18 & 9.1 \\
\hline $1,000,001$ until $2,500,000$ IDR & 18 & 9.1 \\
\hline $2,500,001$ until $5,000,000$ IDR & 44 & 22.2 \\
\hline Above $5,000,001$ IDR & 70 & 35.4 \\
\hline \multicolumn{3}{|l|}{ Health complaints } \\
\hline Have no health complaints & 118 & 59.6 \\
\hline Have health complaints & 80 & 40.4 \\
\hline \multicolumn{3}{|c|}{ Economic conditions during the COVID pandemic 19} \\
\hline Very bad & 79 & 39.9 \\
\hline Bad & 50 & 25.3 \\
\hline Stay safe & 67 & 33.8 \\
\hline Increase & 1 & 0.5 \\
\hline Very increase & 1 & 0.5 \\
\hline \multicolumn{3}{|l|}{ Health conditions during the COVID pandemic 19} \\
\hline Very bad & 12 & 6.1 \\
\hline Bad & 33 & 16.7 \\
\hline Stay safe & 149 & 75.3 \\
\hline Increase & 2 & 1.0 \\
\hline Very increase & 2 & 1.0 \\
\hline \multicolumn{3}{|l|}{ Residence location } \\
\hline Green zone & 56 & 28.3 \\
\hline Yellow zone & 30 & 15.2 \\
\hline Orange zone & 52 & 26.3 \\
\hline Red zone & 60 & 30.3 \\
\hline
\end{tabular}


means that the instrument used in this study has been able to measure the variables validly and reliably.

Hypothesis I testing was conducted to find out whether there was a relationship between the COVID19 pandemic and the health consciousness level. The following is the correlation test:

Table 2 also shows that it is quite negatively correlated. These results indicate that the two variables have an inverse relationship, it implies that the higher the incidence of COVID-19 Pandemic in Indonesia, the health consciousness level decreases.

Table 2: Pearson's correlation testing

\begin{tabular}{lll}
\hline Variables & Significance $(P$-value $)$ & Correlation \\
\hline Health consciousness * COVID-19 pandemic & 0.000 & -0.326 \\
\hline
\end{tabular}

Hypothesis II testing was carried out to find out whether there was a relationship between the COVID19 pandemic and the economic consciousness level. The following is the correlation test:

Based on Table 3, it shows Pearson's correlation coefficient indicates that significant correlations among the economic consciousness and COVID-19 pandemic with $P<0.05$. Table 3 also shows that it is very weakly negatively correlated. These results indicate that the two variables have an inverse relationship, it means that the higher the incidence of the COVID-19 pandemic in Indonesia, the economic consciousness level decreases slightly.

Table 3: Pearson's correlation testing

\begin{tabular}{lll}
\hline Variables & Significance $(P$-value $)$ & Correlation \\
\hline Economic consciousness * COVID-19 pandemic & 0.018 & -0.150
\end{tabular}

Hypothesis 3 testing was undertaken to determine which level of consciousness was higher between health consciousness or economic consciousness during the COVID-19 pandemic. The following is a standard deviation test to determine the distribution of observational data and the tendency of the data to differ from one another.

Based on Table 4, it can be seen that the standard deviation value of 0.97 means that the data are evenly distributed and heterogeneous. Then, testing was continued for the third hypothesis. Following are the test results:

Table 4: Descriptive statistic and one sample t-testing

\begin{tabular}{lllll}
\hline Variable & Sample & Mean & Standard deviation & Significance $(P$-value $)$ \\
\hline Consciousness & 198 & 2.58 & 0.97 & 0.00
\end{tabular}

Based on Table 5, it can be seen that for health consciousness, permanent or formal workers have a

Table 5: Consciousness level

\begin{tabular}{lllllll}
\hline Variables & $\begin{array}{l}\text { Permanent } \\
\text { employee }\end{array}$ & $\begin{array}{l}\text { Big } \\
\text { entrepreneur }\end{array}$ & $\begin{array}{l}\text { SMMEs } \\
\text { entrepreneur }\end{array}$ & $\begin{array}{l}\text { Non formal } \\
\text { employee }\end{array}$ & Total & Percent \\
\hline $\begin{array}{l}\text { High health } \\
\text { consciousness }\end{array}$ & 11 & 1 & 0 & 2 & 14 & 7.07 \\
$\begin{array}{l}\text { Health } \\
\text { consciousness }\end{array}$ & 97 & 1 & 6 & 5 & 109 & 55.05 \\
$\begin{array}{l}\text { Economic } \\
\text { consciousness }\end{array}$ & 1 & 1 & 4 & 16 & 22 & 11.11 \\
$\begin{array}{l}\text { High economic } \\
\text { consciousness }\end{array}$ & 0 & 8 & 10 & 35 & 53 & 26.77 \\
$\begin{array}{l}\text { Total } \\
\text { Percent }\end{array}$ & 109 & 11 & 20 & 58 & 198 & 100 \\
\hline
\end{tabular}

higher health consciousness than other professions. The professions of large entrepreneurs and small, micro, and medium enterprises (SMMEs) entrepreneurs prioritize economic consciousness, as well as nonformal workers. Based on this evidence, it is clear that defined income professions are more supportive of health consciousness than professions with uncertain income.

\section{Discussion}

The results of the study based on the economic level found that the middle to lower economic society is more concerned with economic consciousness than health consciousness due to these people do not have enough savings if they choose to quarantine at home. Meanwhile, the middle class and upper class community care more about health consciousness than economic consciousness because they have sufficient savings if they have to do self quarantine at home. In addition, the middle- and lower-class societies are not so afraid of the coronavirus 19 and they do not care if they are infected by the virus, because they believe life and death have been determined by God.

The results of research based on profession found that people with the merchant profession, especially small and medium traders, are more concerned with economic consciousness than health consciousness, it indicates that these people do not have regular income and consider that COVID-19 is just an ordinary virus. On the other hand, civil servants, health workers, and other professions that have regular and fixed income care more about health consciousness than economic consciousness because they have enough savings if they must do self quarantine at home.

Based on the table consciousness level, all workers still have high health consciousness, while large employers, MSME entrepreneurs, and non-formal workers choose economic consciousness as the most important thing. This was obtained through interviews and direct observation to several respondents from large employers, actors, and non-formal workers. Following are excerpts of interviews with pineapple traders in Pekanbaru City (Informant A):

"amak picayo dengan Covid ko nyo dan takuik juo, tapi baa le nak, amak dan kaluarga butuh makan, butuh baya listrik, lai pemerintah yang suruh tutuik usaho amak ko nio mananggung kebutuhan amak, kalua iyo, bia la amak duduik di umah, itupun ado Tuhan yang menentukan iduik jo mati awak, kalau lah ajal, matinyo, bukan karano covid ajo manusia ko akan mati." [Local Malay Language]

"Ibu percaya dengan Covid dan takut juga sebenarnya. Tapi mau bagaimana lagi. Ibu 
dan keluarga butuh makan, butuh bayar listrik. Apakah pemerintah yang menyuruh untuk menutup usaha Ibu ini mau menanggung kebutuhan Ibu? Kalau iya, biarlah Ibu duduk di rumah saja. Itu pun Tuhan yang menentukan hidup dan mati kita. Kalau sudah ajalnya, matinya, bukan karena Covid saja manusia ini akan mati." [Indonesian]

"I believe that Covid does exists and I am afraid of it too actually. But what can I say. I and my family need food to eat. I need to pay for my electricity too. Does the government would like to cover it all? If yes, then I will just stay at home. Not going anywhere. Nevertheless, God is the one who determine whether we live or we die. If the time comes, our death is not caused by Covid only. There are many other factors that can cause human death." [English Translation]

The next interview was undertaken with a cake production house that has a shop in Kampar Regency (Informant B):

"covid anak uwang covid lah, awak indak pecayo, kalau pun ado, bia lah, awak ado Tuhan yang menentukan iduik dan mati, bukan pemerintah, yang penting aman makan, aman karyawan awak untuk iduiknyo." [Local Malay Language]

"Covid anak orang, covid lah. Kami tidak percaya. Kalaupun ada, biar saja. Tuhanlah yang menentukan hidup dan mati kita. Bukan pemerintah. Yang penting aman makan, aman karyawan kita untuk kehidupannya." [Indonesian]

"I do not care if other peole's child is infected by Covid. We do not believe in it. Even though it does exist, we do not care about it. God is the one who determine our life and death. Not the government. The most important thing is safe food to eat, our employees are also safe for their life." [English Translation]

The excerpt of an interview with a department store entrepreneur in Duri, Bengkalis Regency (Informant C):

"kalau awak percaya dengan covid, cumo awak kan punyo karyawan, sangat terasa turunnya omset, mau pengurangan awak sekarang ini, cumo masih mikir-mikir, awak berharap covid ko cepat berlalu, tapi untuk menutup usaha dengan alasan memutus mata rantai covid ini ga mungkin lah, karyawan awak macam mano, siapa yang mau menjamin hidup karyawan kalau tutup usaha awak." [Local Malay Language]

"Kalau kami percaya dengan Covid, dan kami dalam keadaan memiliki karyawan seperti ini, sangat terasa turunnya omset. Kalau kami ingin pengurangan karyawan, masih mikir-mikir. Kami berharap Covid ini cepat berlalu, tapi untuk menutup usaha dengan alasan memutus mata rantai Covid ini tidak mungkin lah. Karyawan kami bagaimana nanti. Siapa yang mau menjamin hidup karyawan kami kalau kami tutup pula usaha kami ini." [Indonesian]

"If we believe in Covid, and in our condition right now we have employees, we really feel that our turnover decreases. If we would like to decrease a number of employees, we are still thinking about it. We expect that this Covid can be overcomed soon, but to close our business to break the transmission chain of this Covid is impossible. What will happen to our employees later. Who wants to guarantee their life if we close our business." [English Translation]

Based on the results of interviews and direct observations, the researcher concluded that respondents who were not permanent workers, they were more concerned with economic consciousness because no one could guarantee the adequacy of their needs. Respondents who were not permanent workers also believe that illness and death are destiny of God that every human must undergo it. With this condition, this pandemic could not be overcome quickly if there is no consciousness from the entire society. This requires a change in the new life pattern of the society or new normal, which is a change in the pattern of life that must be undertaken by the society with new arrangements and adaptations of habits so that the society can live productively and avoid COVID-19 transmission.

\section{Conclusion}

This study provides evidence that the economic level of the society will determine its health consciousness. The evidence shows that societies with uncertain income are more concerned with economic consciousness than health consciousness. The societies with uncertain income, especially non-formal workers, are also not too afraid of the coronavirus 19 and they do not care if they are infected by the virus, because they believe life and death have been determined by God. Other evidence also shows that respondents who work as small, middle traders and large entrepreneurs are more concerned with economic consciousness than health consciousness, it implies that these people do not have regular income and consider that COVID-19 is just an ordinary virus. Meanwhile, respondents who are employees, health workers, and other professions who have regular income are more concerned about health consciousness than economic consciousness because these people have sufficient savings if they choose to quarantine at home. 


\section{References}

1. DiClemente $\mathrm{C}$. The transtheoretical model of intentional behaviour change. Drugs Alcohol Today. 2007;7(1):29-33. https://doi.org/10.1108/17459265200700007

2. Gould SJ. Health consciousness and health behavior: The application of a new health consciousness scale. Am J Prev Med. 1990;6(4):228-37.

3. Hong $H$. Scale Development for Measuring Health Consciousness: Re-Conceptualization; 2009. p. 21.

4. Karn S, Swain K. Health consciousness through wellness tourism: A new dimension to new age travelers. Afr J Hosp Tour Leis. 2017;6(3):1-9.

5. Voronov VV. The economic consciousness and value orientations of graduates of the higher educational institutions of latgalia [Latvia]. Russ Educ Soc. 2010;52(9):78-88. https:// doi.org/10.2753/res1060-9393520906

6. Hoque M, Alam N, Nahid K. Health consciousness and its effect on perceived knowledge, and belief in the purchase intent of liquid milk: Consumer insights from an emerging market. Foods. 2018;7(9):150. https://doi.org/10.3390/foods7090150

7. Hu CS. A New Measure for Health Consciousness: Development of a Health Consciousness Conceptual Model; 2016. Available from: https://www.mafiadoccoma-new-meas--health-conscious5a812c0d1723dd3578b01c48html. [Last accessed on 2020 Dec 14].

8. Iversen AC, Kraft P. Does socio-economic status and health consciousness influence how women respond to health related messages in media? Health Educ Res. 2006;21(5):601-10. https://doi.org/10.1093/her/cyl014

PMid:16702193

9. Becker DP, Miller JD, Ward JD. The outcome from severe head injury with early diagnosis and intensive management. J Neurosurg. 1977;47(4):491-502. https://doi.org/10.3171/ jns.1977.47.4.0491

PMid: 903803

10. Michaelidou N, Hasan LM. The role of health consciousness, food safety concern and ethical identity on attitudes and intentions towards organic food. Int J Consum Stud. 2008;32(2):163-70. https://doi.org/10.1111/j.1470-6431.2007.00619.x

11. Gould SJ. Consumer attitudes toward health and health care: A differential perspective. J Consum Aff. 1988;22(1):96-118. https://doi.org/10.1111/j.1745-6606.1988.tb00215.x

12. Kraft FB, Goodnell PW. Identifying the health conscious consumer. J Health Care Mark. 1993;13(3):18-25. PMid:10129812

13. Jayanti RK, Burns AC. The antecedents of preventive health care behavior: An empirical study. J Acad Mark Sci. 1998;26(1):6-15.

14. Dutta-Bergman MJ. Primary sources of health information: Comparisons in the domain of health attitudes, health cognitions, and health behaviors. Health Commun. 2004;16(3):273-88. https://doi.org/10.1207/s15327027hc1603_1

\section{PMid:15265751}

15. Dutta-Bergman MJ. Health attitudes, health cognitions, and health behaviors among Internet health information seekers: Population-based survey. J Med Internet Res. 2004;6(2):e15. https://doi.org/10.2196/jmir.6.2.e15 PMid: 15249264

16. Dutta-Bergman MJ. Media use theory and internet use for health care. In: The internet and Health Care: Theory, Research, and Practice. London: Routledge; 2006. p. 83-103.

17. Dutta-Bergman MJ. Health information processing from television: The role of health orientation. Health Commun. 2007;21(1):1-9.

PMid:17461747

18. Furnham A, Forey J. The attitudes, behaviors and beliefs of patients of conventional vs. complementary (alternative) medicine. J Clin Psychol. 1994;50(3):458-69. https:// doi.org/10.1002/1097-4679(199405)50:3<458:aidjclp2270500318>3.0.co;2-v PMid:8071452

19. Dutta-Bergman MJ. Theory and practice in health communication campaigns: A critical interrogation. Health Commun. 2005;18(2):103-22. https://doi.org/10.1207/ s15327027hc1802_1

PMid: 16083406

20. Basu A, Dutta-Bergman MJ. The relationship between health information seeking and community participation: The roles of health information orientation and efficacy. Health Commun. 2008;23(1):70-9. https://doi.org/10.1080/10410230701807121 PMid: 18443994

21. Dutta-Bergman MJ, Feng $\mathrm{H}$. Health orientation and disease state as predictors of online health support group use. Health Commun. 2007;22(2):181-9. https://doi.org/10.1080/10410230701310323 PMid: 17668997

22. Moorman C, Matulich E. A model of consumers' preventive health behaviors: The role of health motivation and health ability. J Consum Res. 1993;20(2):208-28. https://doi. org/10.1086/209344

23. Puri LM. Transitioning to the future of work-the power of possibility. Jindal J Public Policy. 2017;5(1):16-29.

24. Golubeva EV, Golubeva IV. Deformations in economic consciousness of children raised in orphanages. SAGE Open. 2015;5(3):1-7. https://doi.org/10.1177/2158244015604191

25. Nevelev AB, Kamaletdinova AY. Economic Consciousness as an Idealema: An Analysis of k. Marx's Works; 2019. Available from: https://www.cyberleninka.ru/article/n/economic-consciousnessas-an-idealema-an-analysis-of-k-marx-s-works/pdf. [Last accessed on 2020 Dec 31].

26. Duppe T. Economic Consciousness; 2018. Available from: https://www.irpcdn.multiscreensite.com/ada76a6e/files/ uploaded/economic\%20consciousness\%20duppe.pdf. [Last accessed on 2020 Nov 16].

27. Chen H, Volpe RP. An analysis of personal financial literacy among college students. Financ Serv Rev. 1998;7(2):107-28. 